\title{
Human pancreatic duct cells can produce tumour necrosis factor- $\alpha$ that damages neighbouring beta cells and activates dendritic cells
}

\author{
B. Movahedi ${ }^{1} \cdot$ M. Van de Casteele ${ }^{1} \cdot$ N. Caluwé1 $\cdot$ G. Stangé ${ }^{1} \cdot$ K. Breckpot ${ }^{2} \cdot$ K. Thielemans ${ }^{2}$. \\ G. Vreugdenhil ${ }^{3}$. C. Mathieu ${ }^{4}$. D. Pipeleers ${ }^{1}$ \\ ${ }^{1}$ Diabetes Research Centre, Brussels Free University_VUB and JDRF Centre for Beta Cell Therapy in Europe, Brussels, \\ Belgium \\ ${ }^{2}$ Laboratory of Molecular and Cellular Therapy, Department of Physiology and Immunology, Brussels Free University-VUB, \\ Belgium \\ ${ }^{3}$ Department of Medical Microbiology, University Medical Centre Nijmegen, The Netherlands \\ ${ }^{4}$ Laboratory of Experimental Medicine and Endocrinology, Catholic University of Leuven-KUL, Belgium
}

\begin{abstract}
Aims/hypothesis. In the human pancreas, a close topographic relationship exists between duct cells and beta cells. This explains the high proportion of duct cells in isolated human islet preparations. We investigated whether human duct cells are a source of TNF $\alpha$-mediated interactions with beta cells and immune cells. This cytokine has been implicated in the development of autoimmune diabetes in mice.

Methods. Human duct cells were isolated from donor pancreases and examined for their ability to produce TNF $\alpha$ following a stress-signalling pathway. Ductcell-released TNF $\alpha$ was tested for its in vitro effects on survival of human beta cells and on activation of human dendritic cells.

Results. Exposure of human pancreatic duct cells to interleukin-1 $\beta$ (IL-1 $\beta$ ) induces TNF $\alpha$ gene expres-
\end{abstract}

sion, synthesis of the $26,000 \mathrm{M}_{\mathrm{r}} \mathrm{TNF} \alpha$ precursor and conversion to the $17,000 \mathrm{M}_{\mathrm{r}}$ mature form, which is rapidly released. This effect is NO-independent and involves p38 MAPK and NF-кB signalling. Duct-cellreleased TNF $\alpha$ contributed to cytokine-induced apoptosis of isolated human beta cells. It also induced activation of human dendritic cells.

Conclusions/interpretation. Human pancreatic duct cells are a potential source of $\mathrm{TNF} \alpha$ that can cause apoptosis of neighbouring beta cells and initiate an immune response through activation of dendritic cells. They may thus actively participate in inflammatory and immune processes that threaten beta cells during development of diabetes or after human islet cell grafts have been implanted.

Keywords Apoptosis - Diabetes mellitus · Insulin · Islets of Langerhans · Pancreas
Received: 16 December 2003 / Accepted: 17 April 2004

Published online: 8 June 2004

C) Springer-Verlag 2004

D. Pipeleers $(\varangle)$

Diabetes Research Centre,

Brussels Free University-VUB and JDRF Centre

for Beta Cell Therapy in Europe,

Laarbeeklaan 103, 1090 Brussels, Belgium

E-mail: Daniel.Pipeleers@vub.ac.be

Tel.: +32-2-4774541, Fax: +32-2-4774545

Abbreviations: CK-19, Cytokeratin $19 \cdot$ DuC, duct cell $\cdot$ iNOS, inducible nitric oxide synthetase $\cdot$ JNK, jun N-terminal kinase MAPK, mitogen activated protein kinase $\cdot \mathrm{NF}-\kappa \mathrm{B}$, nuclear factor kappa B - NOD mouse, non-obese diabetic mouse

\section{Introduction}

Inflammatory infiltration of pancreatic islets is considered a major pathogenic event in the development of Type 1 diabetes. Insulitis is noticed at clinical onset of the disease [1], particularly in patients younger than 15 years [2], and found to contain a mixture of reactive lymphocytes [3]. A form of insulitis was also detected in rodents developing autoimmune diabetes [4]. In (pre)diabetic non-obese diabetic mice (NOD), infiltrating lymphocytes and macrophages were shown to produce cytokines $[5,6,7,8]$ that can destroy pancreatic beta cells in vitro $[9,10]$. Cytokines were therefore proposed as potential mediators of beta cell death in vivo. Studies in NOD mice have suggested that $\mathrm{TNF} \alpha$ is involved in the in vivo process leading to 
beta cell death $[11,12,13,14,15,16]$. While studying the influence of cytokines on human pancreatic cell preparations, we noticed that several effects were primarily exerted on duct cells instead of on beta cells; this was the case for their induction of MHC-class II expression [17], and of nitric oxide synthetase expression leading to NO production $[18,19]$. This led to the view that duct cells might be actively involved in immune and inflammatory processes that surround beta cells during development of diabetes and after islet cell transplantation [19]. The human pancreas is indeed characterised by a close anatomic association of duct cells and islet beta cells [20], which explains why isolated human islet cell preparations contain relatively large proportions of duct cells [21, 22] that are attached to beta cells (unpublished observations). It is therefore conceivable that in situ as well as in preparations used in vitro or for transplantation, a fraction of beta cells is directly exposed to duct cell products [19]. Our study demonstrates this notion and shows that TNF $\alpha$ qualifies as one of these products, with potential effects on islet beta cells and on dendritic cells.

\section{Materials and methods}

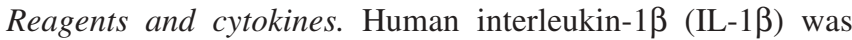
kindly provided by Dr Reynolds (NCI-FCRDC Frederick, Md., USA), human interferon gamma (IFN- $\gamma$ ), IL-6 and TNF $\alpha$ was purchased from Peprotech (Rocky Hill, N.J., USA), human IL-4 from Brucells (Brussels, Belgium), GM-CSF from Novartis (Basel, Switzerland), mouse recombinant TNF $\alpha$ (mTNF $\alpha)$ and anti-human $\mathrm{TNF} \alpha$ neutralising antibody from R\&D systems (Minneapolis, Minn., USA), cycloheximide (CHX), actinomycin D (ACTD), Brefeldin A, SB203580 and PGE2 from SigmaAldrich (St. Louis, Mo., USA), SP600125 and MG-132 from Biomol Research Laboratories (Plymouth Meeting, Pa., USA).

Duct cell isolation and culture. Human pancreatic duct cells were prepared from donor organs that were procured by transplant departments affiliated to Eurotransplant Foundation (Leiden, the Netherlands). The organs were sent to the Human Beta Cell Bank in Brussels for preparation of beta cell grafts to be used in a clinical trial [22]. The use of donor organs and of isolated fractions followed the guidelines of Eurotransplant, and of protocols that were approved by the ethics committee of Brussels Free University-VUB. The techniques for preparation of duct cells have been described [17]. Briefly, after collagenase digestion of the pancreas and Ficoll gradient centrifugation of the digest, the non-endocrine fraction is recovered and cultured as suspension in serum-free medium for 3 to 7 days. Virtually all acinar cells disappeared during this period. The preparation was then further cultured in 24 or 6-well tissue culture plates (Falcon, Becton Dickinson, N.J., USA), withrespectively $-2 \times 10^{5}$ or $10^{6}$ cells per well in HAM's F-10 medium (Gibco BRL, Life Technologies, Paisley, UK) supplemented with $7.5 \mathrm{mmol} / \mathrm{l}$ glucose (Merck, Darmstadt, Germany), $0.5 \%$ bovine serum albumin (Roche Diagnostics, Mannheim, Germany), $0.1 \mathrm{mg} / \mathrm{ml}$ streptomycin (Sigma Chemical, St Louis, Mo., USA), $0.075 \mathrm{mg} / \mathrm{ml}$ penicillin (Continental Pharma, Brussels, Belgium) and $0.3 \mathrm{mg} / \mathrm{ml} \mathrm{L-glutamine} \mathrm{(Gibco}$ BRL, Life Technologies, Paisley, UK). Fetal calf serum was present during the first 4 days (10\% heat inactivated; Gibco
BRL, Life Technologies, Paisley, UK) in order to facilitate monolayer formation. Once monolayers were established, the cells were washed and experiments were performed in serumfree medium. Duct cell supernatant used for beta cell viability and dendritic cell experiments was obtained from duct cell monolayers after a $24 \mathrm{~h}$ culture with or without IL-1 $330 \mathrm{U} / \mathrm{ml}$. Supernatants were collected, centrifuged and stored at $-20{ }^{\circ} \mathrm{C}$ prior to use.

Analysis of TNF $\alpha$ and of nitrite formation. Monolayers of human pancreatic duct cells were incubated for 1.5 to $72 \mathrm{~h}$ in serum-free medium with or without cytokines. Nitrites and $\mathrm{TNF} \alpha$ were assayed in the supernatants. The hTNF $\alpha$ levels were measured by ELISA (BioSource International, Camarillo, Calif., USA) using calibration with the international standard preparation (87/650-NIBC, Hertfordshire, EN6 3QG-1 $\mu \mathrm{g}$ equals $40,000 \mathrm{U})$. Nitrites were determined spectrophotometrically at $546 \mathrm{~nm}$ after a Griess reaction [23]. For immunoblotting studies cells were lysed in $50 \mathrm{mmol} / \mathrm{l}$ Tris $(\mathrm{pH} \mathrm{7.5)}$, $150 \mathrm{mmol} / \mathrm{l}$ sodium chloride, $1 \%$ deoxy cholic acid (wt/vol), $1 \%$ Igepal CA-630 (vol/vol), 0.1\% SDS (wt/vol), 2 mmol/l EDTA, phosphatase inhibitors $(50 \mathrm{mmol} / \mathrm{l}$ sodium fluoride, $10 \mathrm{mmol} / \mathrm{l}$ sodium orthovanadate, $10 \mathrm{mmol} / \mathrm{l} \beta$-glycerophosphate, $10 \mathrm{mmol} / 1 \mathrm{p}$-nitophenylphosphate, $1 \mathrm{mmol} / \mathrm{l}$ sodium pyrophosphate) and proteinase inhibitors (leupeptine, antipain, benzamidine, trypsin inhibitor; chymostatin, pepstatin A). Samples were frozen in liquid nitrogen and kept at $-80^{\circ} \mathrm{C}$ until processed. Before analysis, thawed samples were sonicated and cleared by centrifugation. Protein concentration was measured by a commercial colorimetric assay (Pierce, Rockford, Ill., USA). For immunoblotting, samples with $50 \mu \mathrm{g}$ protein were mixed with an equal volume of two times concentrated sample buffer [10\% SDS (wt/vol), 10\% $\beta$-mercaptoethanol (vol/vol), $160 \mathrm{mmol} / \mathrm{l}$ Tris- $\mathrm{HCl}$ ( $\mathrm{pH} 6.8), 10 \mathrm{mmol} / \mathrm{l}$ EDTA, $20 \%$ glycerol (vol/vol), and $1 \mathrm{mmol} / \mathrm{l}$ phenylmethylsulphonyl fluoride] and run on $15 \%$ SDS-polyacrylamide together with the Benchmark prestained molecular weight marker (Life Technologies, Paisley, UK). After electrophoresis, samples were electroblotted to nitrocellulose filters (Protran, Schleicher and Schuell, Keen, $\mathrm{NH}$ ). Blots were incubated, first for $1 \mathrm{~h}$ at room temperature in $5 \%$ non-fat dry milk/Tris buffered saline (TBS) and then overnight at $4{ }^{\circ} \mathrm{C}$ with anti-human $\mathrm{TNF} \alpha$ (R\&D Systems, Minneapolis, Minn., USA), anti-phospho-c-jun and anti- $\beta$ actin (Santa Cruz Biotechnology, Santa Cruz, Calif., USA), anti-human iNOS (Transduction Laboratories, Lexington, Ky., USA), anti-Phospho-JNK, anti-Phospho-p38 (New England Biolabs, Beverly, Mass., USA). Horseradish peroxidase-linked anti- (goat, rabbit or mouse) IgG (Santa Cruz Biotechnology, Santa Cruz, Calif., USA) was used as second antibody for $1 \mathrm{~h}$ at room temperature and the peroxidase activity was detected by enhanced chemiluminescence (Amersham, Buckinghamshire, UK) and photosensitive film (Biomax ML; Kodak, Rochester, N.Y., USA).

Real time RT-PCR. Total RNA was extracted by TRIzol reagent (Invitrogen Corporation/Life Technologies, Carlsbad, Calif., USA), and cDNA prepared by reverse transcription; $5 \mu \mathrm{mol} / \mathrm{l}$ Oligo $(\mathrm{dT})_{16}$ (Applied Biosystems, Foster City, Calif., USA) was added to $0.5 \mu \mathrm{g}$ of total RNA, heated to $72{ }^{\circ} \mathrm{C}$ for $10 \mathrm{~min}$ and then cooled on ice. Next, 100 units of Superscript II (Invitrogen Corporation/Life Technologies) were added to RNA-oligo (dT) mixture, together with $50 \mathrm{mmol} / \mathrm{l}$ Tris- $\mathrm{HCl}$ ( $\mathrm{pH} \mathrm{8.3),} 75 \mathrm{mmol} / \mathrm{l} \mathrm{KCl}, 3 \mathrm{mmol} / \mathrm{l} \mathrm{MgCl}_{2}, 5 \mathrm{mmol} / \mathrm{l} \mathrm{dNTPs}$, and incubated at $42{ }^{\circ} \mathrm{C}$ for $80 \mathrm{~min}$. Real time PCR was performed using the ABI prism 7700 SDS (Applied Biosystems) in combination with TaqMan chemistry. Primers and probe sequences for human TNF $\alpha$ were as described [24]. Hypo- 
xanthine phosphoribosyltransferase 1 (HPRT) was used as housekeeping gene to normalise TNF $\alpha$ values. HPRT primers and probe sequences are as follows: F 5'-TGTAGGATATGCCCTTGACTATA-3' R 5'-CAATAGGACTCCAGATGTTTCCA3' P 5'-TGGAAAAGCAAAATACAAAGCCTAAGATGAG$3^{\prime}$. PCR amplifications were carried out in duplicate in a total volume of $25 \mu \mathrm{l}$ containing $0.5 \mu \mathrm{l}$ cDNA sample, $50 \mathrm{mmol} / \mathrm{l}$ $\mathrm{KCl}, 10 \mathrm{mmol} / \mathrm{l}$ Tris-HCl (pH 8.3), $10 \mathrm{mmol} / \mathrm{l}$ EDTA, 60 nmol/l Passive Reference, $1200 \mu \mathrm{mol} / \mathrm{l}$ dNTPs, 3 to $9 \mathrm{mmol} / \mathrm{l} \mathrm{MgCl}_{2}, 100$ to $900 \mathrm{nmol} / \mathrm{l}$ of each primer, $100 \mathrm{mmol} / \mathrm{l}$ of TaqMan probe and $0.625 \mathrm{U}$ AmpliTaqGold (Applied Biosystems). Thermal conditions: $10 \mathrm{~min}$ at $94{ }^{\circ} \mathrm{C}$, followed by 45 two temperature cycles $\left(15 \mathrm{~s}\right.$ at $94{ }^{\circ} \mathrm{C}$ and $1 \mathrm{~min}$ at $60^{\circ} \mathrm{C}$ ). cDNA plasmid standards were used for each target to quantify relative expression [24].

Immunocytochemistry. For TNF $\alpha$ and CK-19 staining, duct cell monolayers were fixed at room temperature in $4 \%$ buffered formaldehyde and then permeabilised with Triton$\mathrm{X} 100$ before incubation in $10 \mathrm{mmol} / \mathrm{l} \mathrm{EDTA}$ at $70{ }^{\circ} \mathrm{C}$ for $10 \mathrm{~min}$. Non-specific binding sites were blocked by $10 \%$ normal goat serum or $2 \%$ normal donkey serum prior to, respectively, TNF $\alpha$ and CK19 immunostaining using mouse antihuman TNF $\alpha$ mAb (HyCult biotechnology b.v., The Netherlands) and sheep anti-human CK19 Ab (The Binding Site, Birmingham, UK). The cells were then washed in PBS and incubated with Texas Red conjugated secondary donkey antimouse $\mathrm{mAb}$ or Cy2-conjugated secondary donkey anti-sheep $\mathrm{Ab}$ (both from Jackson ImmunoResearch Laboratories, West Grove, Pa., USA). After washing, the preparations were mounted, covered by Dako fluorescence mounting medium (Dako Corporation, Carpinteria, Calif., USA) and analysed by a Leica TCS SP confocal laser-scanning microscope (CLSM). The CLSM is equipped with $\mathrm{Ar} / \mathrm{HeNe}$-lasers and Leica TCS NT software (version 1.6.587). Fluoresbrite grade microspheres, ( $\varnothing 3.0 \mu \mathrm{m}$, Polylab BVBA, Belgium) were used to calibrate the magnification. Images were transferred to Adobe PhotoShop 5.5 software for multicolour channel analysis and figure assembly. For subcellular localisation of the P65 subunit of $\mathrm{NF}-\kappa \mathrm{B}$, monolayers were fixed and permeabilised by icecold acetone before incubation with primary rabbit anti-human NF-kB-P65 antibody (Santa Cruz Biotechnology, Santa Cruz, Calif., USA). After washing in PBS, the preparations were incubated with $\mathrm{Cy} 3$-conjugated secondary donkey anti-rabbit $\mathrm{Ab}$ (Jackson ImmunoResearch Laboratories, West Grove, Pa., USA), washed again, mounted and analysed in a Axioplan 2 fluorescence microscope (Carl Zeiss Jena, Jena, Germany) equipped with Photometrics SenSys 1401 digital Camera (vysys, France) and Smart Capture VP (version 1.4) software (Digital Scientific, UK).

Beta cell toxicity assay. Human beta cell preparations were obtained from the Human Beta Cell Bank. Methods for isolation, dissociation, purification and culture have been described elsewhere $[21,22]$. The cultured endocrine fraction was dissociated and enriched in single beta cells by flow cytometry (FACS sorting) according to forward scatter and autofluorescence intensity at $530 \mathrm{~nm}$ [25]; the degree of purity is lower than that for rat beta cells but routinely exceeds $60 \%$. The purified beta cell preparation was cultured in micro titer cups at 4000 cells per well in a HAM F-10 basis of unconditioned or duct cell (DuC) conditioned medium with replacement of half the volume every 2 days. Cells cultured in unconditioned HAM F10 without cytokines served as controls. The effect of IL-1 $\beta$ was also tested in unconditioned medium with or without recombinant human TNFo added. An anti-human TNF $\alpha$ neutralising antibody was added in two conditions. Each beta cell prepara- tion was incubated with conditioned media of three different duct cell preparations and each condition was carried out in duplicate. After 10 days of culture, the percentages of apoptotic and necrotic cells were determined as described previously [26]. The apoptosis index was calculated as: (\% apoptotic cells in test-\% apoptotic cells in control condition $) /(100-\%$ apoptotic cells in control condition $) \times 100$. The necrosis index was calculated by replacing the percentage of apoptotic cells by the percentage of necrotic cells [27].

Dendritic cell activation assay. Dendritic cells were isolated as described [28] with minor modifications to increase dendritic cell yields [29]. Briefly, peripheral blood mononuclear cells were isolated from buffy coat preparations of healthy donors by gradient centrifugation (Lymphoprep, Nycomed Pharma AS, Oslo, Norway). The cells were seeded in RPMI 1640 (Gibco, Invitrogen, Merelbeke, Belgium) containing $1 \%$ human $\mathrm{AB}$ serum (PAA Laboratories, Linz, Austria), and incubated for $2 \mathrm{~h}$ to allow adherence of monocytes. After washout of non-adherent cells, adherent cells were further cultured for 5 days in the presence of GM-CSF $(1000 \mathrm{U} / \mathrm{ml})$ and IL-4 $(100 \mathrm{U} / \mathrm{ml})$. They were then transferred to culture conditions in DuC-conditioned medium or with a cytokine mixture that is known to activate dendritic cells [30] namely IL-1 $\beta$ (100 U/ml), IL-6 (1000 U/ml), TNF $\alpha$ (100 U/ml) plus Prostaglandin E2 (PGE2, $1 \mu \mathrm{g} / \mathrm{ml})$. Dendritic cell activation was analysed by flow cytometry [31] after staining with PE conjugated monoclonal antibodies against CD25, CD80 and CD83 or isotype controls (BD Pharmingen, Erembodegem, Belgium).

Statistical methods. Results are expressed as means \pm SEM of $n$ independent experiments each using cells from a different donor. Statistical analysis was done using the SPSS computer program. Student's $t$ test was used to compare means of two groups, one way ANOVA with post hoc LSD to compare means of three or more groups, and Friedman test and MannWhitney $\mathrm{U}$ test to compare results that were normalised to the control. Significant differences were based on a $p$ value of less than 0.05 .

\section{Results}

IL-1 $\beta$-induction of TNF $\alpha$ release from human duct cells. Human duct cell monolayers released marginally detectable TNF $\alpha$ levels, i.e. 100 to $200 \mathrm{pg}$ TNF $10^{6} \cdot$ cells $^{-1} .72 \mathrm{~h}^{-1}$. Addition of IL-1 $\beta(30 \mathrm{U} / \mathrm{ml})$ increased TNF-levels 20 fold (Fig. 1a), while no stimulation was seen with human IFN- $\gamma(1-1000 \mathrm{U} / \mathrm{ml}$, data not shown). IL-1 $\beta$ induced TNF $\alpha$ release is detected from $60 \mathrm{~min}$ on, proceeds linearly during the first $6 \mathrm{~h}$ and then levels off to slower increment rates (Fig. 1a). In the period between 12 and $72 \mathrm{~h}$, the rate of TNF $\alpha$ release was only $20 \%$ of that during the first $12 \mathrm{~h}$. The half-maximal effect was reached after $5 \mathrm{~h}$ exposure (Fig. 1a). A similar curve was obtained with $3 \mathrm{U} / \mathrm{ml}$ IL-1 $\beta$ with values that were, on average, $40 \%$ lower than those at $30 \mathrm{U} / \mathrm{ml}$ (Fig. 1a). The lower TNF $\alpha$ increment beyond $12 \mathrm{~h}$ of IL- $1 \beta$ exposure was not caused by inactivation of the stimulus, since adding fresh IL-1 $\beta$ every $12 \mathrm{~h}$ did not further increase TNF $\alpha$ levels in the medium. Nor was it caused by degrada- 


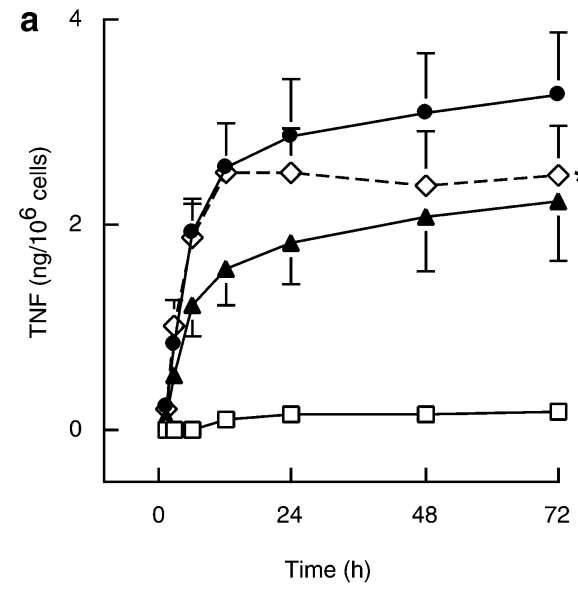

Fig. 1. Effects of IL-1 $\beta$ and IFN- $\gamma$ on TNF $\alpha$ secretion and NO production by human pancreatic duct cells. TNF $\alpha$ (a) and nitrite (b) production by human pancreatic duct cells $\left(2 \times 10^{5} / \mathrm{ml}\right)$ exposed to IL-1 $\beta$ at $3 \mathrm{U} / \mathrm{ml}(\boldsymbol{\Delta}), 30 \mathrm{U} / \mathrm{ml}(\boldsymbol{)})$ or $30 \mathrm{U} / \mathrm{ml}$ of IL-1 $\beta$ plus IFN- $\gamma(100 \mathrm{U} / \mathrm{ml})(\diamond--\diamond)$. Control cells were cultured in medium only $(\square)$. At indicated time points, media were retrieved and TNF $\alpha$ and nitrites determined as described in Materials and methods. Values are means of four independent experiments \pm SEM. $* p<0.05$ vs IL- $1 \beta$ alone

tion of released TNF $\alpha$ during prolonged culture, since medium replacement every $12 \mathrm{~h}$ did not increase $\mathrm{TNF} \alpha$ levels (data not shown).

TNF $\alpha$ release depends on de novo synthesis and conversion of TNF $\alpha$. IL- $1 \beta$ induced TNF $\alpha$ release was associated with de novo synthesis of $\mathrm{TNF} \alpha$ as the $26,000 \mathrm{M}_{\mathrm{r}}$ precursor and its $17,000 \mathrm{M}_{\mathrm{r}}$ biologically active conversion product (Fig. 2a). No induction of TNF $\alpha$ expression was seen with IFN- $\gamma$ or with mouse TNF $\alpha$ (Fig. 2a), and neither stimulated TNF $\alpha$ release (data not shown). Inhibitors of translation (cycloheximide) or transcription (actinomycin D) suppressed IL-1 $\beta$-induced TNF $\alpha$ expression (Fig. 2a); they also inhibited TNF $\alpha$ release by more than $70 \%$ (Fig. 3). Their suppressive effect was not the result of cytodestruction as no increased cell death was measured during this culture period. The inhibitory effect of actinomycin D on TNF $\alpha$ production suggested that IL- $1 \beta$ can induce TNF $\alpha$ gene expression. This was confirmed by quantitative real time PCR (Fig. 2c). Adding Brefeldin A to the IL- $1 \beta$ condition selectively and strongly increased the 26,000 $\mathrm{M}_{\mathrm{r}}$ band (Fig. 2a) which is compatible with its well known disrupting effect on intracellular transport and conversion processes [32]. This condition also blocked IL-1 $\beta$-induced TNF $\alpha$ release (Fig. 3).

The IL-1 $\beta$-induced expression of the TNF $\alpha$ precursor was strongest during the first $6 \mathrm{~h}$ (Fig. 2b), which is also the period of the highest release rate (Fig. 1a). The 26,000 $\mathrm{M}_{\mathrm{r}}$ band became faint at 12 and $24 \mathrm{~h}$, while the $17,000 \mathrm{M}_{\mathrm{r}}$ band disappeared. The lower release rates at these time points are thus not caused by

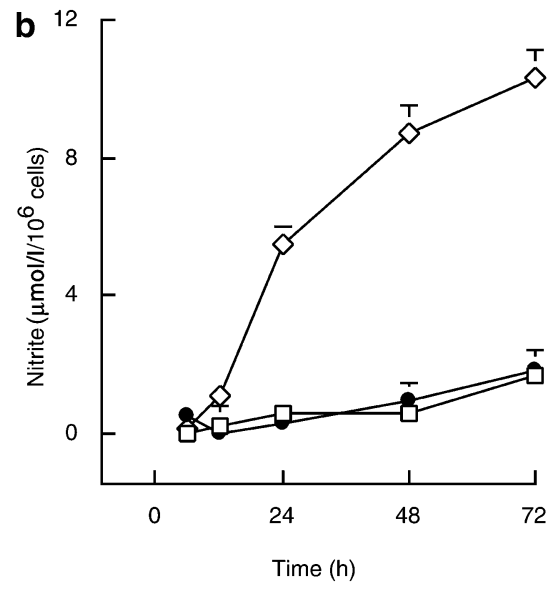

an inhibition of conversion or release, but by a lower rate of biosynthesis.

IL-1 $\beta$ induced effects on TNF $\alpha$ were not associated with an induction of iNOS (data not shown) or an increase in nitrite release (Fig. 1b). The combination of IL- $1 \beta$ plus IFN- $\gamma$ did induce iNOS expression within $6 \mathrm{~h}$ (data not shown) resulting in a subsequent increase in medium nitrite (Fig. 1b). Adding IFN- $\gamma$ did not suppress IL-1 $\beta$-induced TNF $\alpha$ expression (Fig. 2). On the contrary, it caused a time-dependent increase of the $17,000 \mathrm{M}_{\mathrm{r}}$ band over the 24-h study period, together with an increased and prolonged intensity of the 26,000 $\mathrm{M}_{\mathrm{r}}$ band (Fig. 2b). The IFN- $\gamma$ induced suppression of TNF $\alpha$ release beyond $12 \mathrm{~h}$ (Fig. 1a) can therefore not be attributed to a block in TNF $\alpha$ synthesis or conversion, but rather to an inhibition of TNF $\alpha$ discharge into the medium.

Immunocytological evidence for TNF $\alpha$ production by human duct cells. Immunocytochemistry was used to identify the cells responsible for $\mathrm{TNF} \alpha$ production. We selected the condition with the highest intracellular TNF $\alpha$ expression, i.e. the combination of IL- $1 \beta$ and Brefeldin A (Fig. 2a). In these preparations of 70 to $90 \%$ CK-19-marked duct cells, more than $50 \%$ of the cells stained positively for TNF $\alpha$ (Fig. 4). Virtually all TNF $\alpha$ positive cells were positive for CK19 (Fig. 4). Their cytoplasmic staining pattern was similar to that described in other cell types [33]; control preparations exhibited only a faint staining. Thus we concluded that duct cells are responsible for TNF $\alpha$ production and not a contaminating cell type.

TNF $\alpha$ production mediated by $p 38$ MAPK and the $N F-\kappa B$ signalling pathway. IL- $1 \beta$ induced phosphorylation of the MAP-kinases p38 and JNK and of c-jun within $15 \mathrm{~min}$ (Fig. 5). These activations preceded expression of pro-TNFo, which became clearly detectable after $60 \mathrm{~min}$ (Fig. 5). The activated state of p38 was maintained for $6 \mathrm{~h}$ and then disappeared. Phosphorylated forms of JNK and c-jun were also more prominent during this period. These activations were associated with an activation of NF- $\mathrm{KB}$ as indi- 

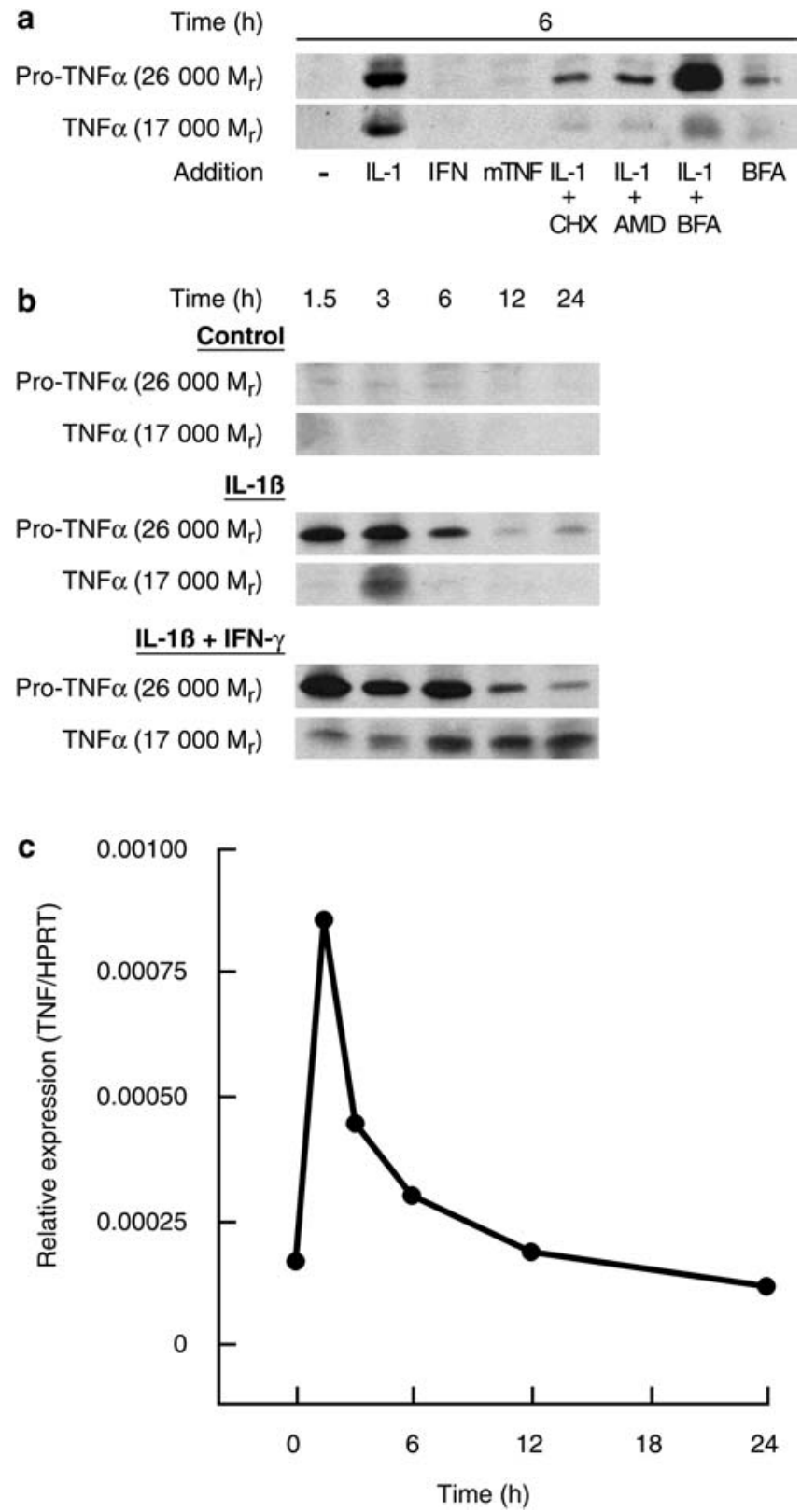

Fig. 2. Effects of cytokines on cellular expression of TNF $\alpha$. Monolayers of human pancreatic duct cells were exposed for the indicated periods to IL-1 $\beta$ (IL-1; $30 \mathrm{U} / \mathrm{ml}$ ), IFN- $\gamma$ (IFN; $100 \mathrm{U} / \mathrm{ml})$, or murine TNF $\alpha$ (mTNF; $100 \mathrm{U} / \mathrm{ml})(\mathbf{a})$. The effect of IL-1 $\beta(30 \mathrm{U} / \mathrm{ml})$ was examined in the absence and presence of cycloheximide (CHX; $5 \mu \mathrm{g} / \mathrm{ml}$ ), actinomycin D (AMD; $1 \mu \mathrm{g} / \mathrm{ml})$ or Brefeldin A (BFA; $5 \mu \mathrm{g} / \mathrm{ml})(\mathbf{a})$, or IFN- $\gamma$ (100 U/ml) (b). Whole cell lysates were separated by SDSPAGE and immunoblotted with TNF $\alpha$ antibody. c. Real time PCR of TNF $\alpha$ expression after extraction of total RNA and reverse transcription to $\mathrm{CDNA}$. TNF $\alpha$ values were normalised to HPRT levels. The figure represents three independent experiments

cated by its nuclear translocation after 15 to $30 \mathrm{~min}$ (data not shown). Adding SB203580, a specific inhibitor of p38 MAPK [34], suppressed IL-1 $\beta$-induced TNF $\alpha$ expression and secretion by more than $75 \%$ (Fig. 6). TNF $\alpha$ release was also inhibited by MG-132,

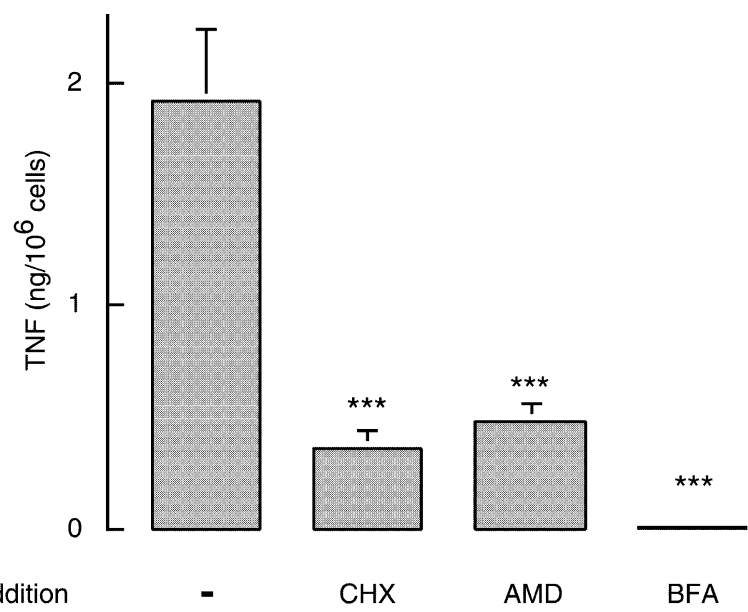

Fig. 3. Effects of cycloheximide (CHX), actinomycin D (AMD), and Brefeldin A (BFA) on IL-1 $\beta$ induced TNF $\alpha$ secretion. Monolayers of human pancreatic duct cells were exposed for $6 \mathrm{~h}$ to $30 \mathrm{U} / \mathrm{ml}$ of IL-1 $\beta$ with or without cycloheximide $(5 \mu \mathrm{g} / \mathrm{ml})$, actinomycin D $(1 \mu \mathrm{g} / \mathrm{ml})$ or Brefeldin A $(5 \mu \mathrm{g} / \mathrm{ml})$. Values are means \pm SEM of four independent experiments. $* * * p<0.001$ vs IL- $1 \beta$ alone

an inhibitor of $\mathrm{I} \kappa \mathrm{B}$ degradation and hence of NF- $\kappa \mathrm{B}$ activation [35] (Fig. 6). On the other hand, SP600125, a specific inhibitor of JNK [36] did not decrease TNF $\alpha$ production (Fig. 6).

Cytotoxic effect of duct-cell-released TNF $\alpha$ on human beta cell preparations. Medium was collected from 24-h duct-cell cultures in the absence (DuC-Co) or presence of $30 \mathrm{U} / \mathrm{ml}$ of IL-1 $\beta$ (DuC-IL-1) (DuC, Fig. 7). The TNF $\alpha$ concentration in DuC-IL-1 varied between 300 and $600 \mathrm{pg} / \mathrm{ml}$, while that in DuC-Co was either undetectable $(<15 \mathrm{pg} / \mathrm{ml})$ or lower than $50 \mathrm{pg} / \mathrm{ml}$. These media were added to cultures of human beta cells to investigate their effect on cell survival. Parallel cultures were done in medium without DuC-supernatant added (no-DuC, Fig. 7), either with or without IL-1 $\beta(30 \mathrm{U} / \mathrm{ml})$ or IL-1 $\beta(30 \mathrm{U} / \mathrm{ml})$ plus human TNFo (400 pg/ml). The condition without supernatant and cytokines served as control. The cytotoxic effect of the test conditions was normalised to this control [26].

Duct cell medium (DuC-Co) did not exert a cytotoxic effect, as the percentages of apoptotic and necrotic cells were comparable to control values (Fig. 7). On the other hand, DuC-IL-1 medium induced apoptosis whereas this was not the case when only IL-1 was added (no DuC-IL-1, Fig. 7). This apoptotic effect was partially suppressed by a neutralising anti$\mathrm{TNF} \alpha$ antibody, suggesting its dependency on TNF $\alpha$ that is present in DuC-IL-1 medium. Apoptosis also occurred in control medium containing IL-1 plus $\mathrm{TNF} \alpha$ at $400 \mathrm{pg} / \mathrm{ml}$ (no DuC-IL-1+TNF), the concentration that was measured in DuC-IL-1 medium. Apoptosis was partially suppressed by the anti-TNF $\alpha$ 
Control
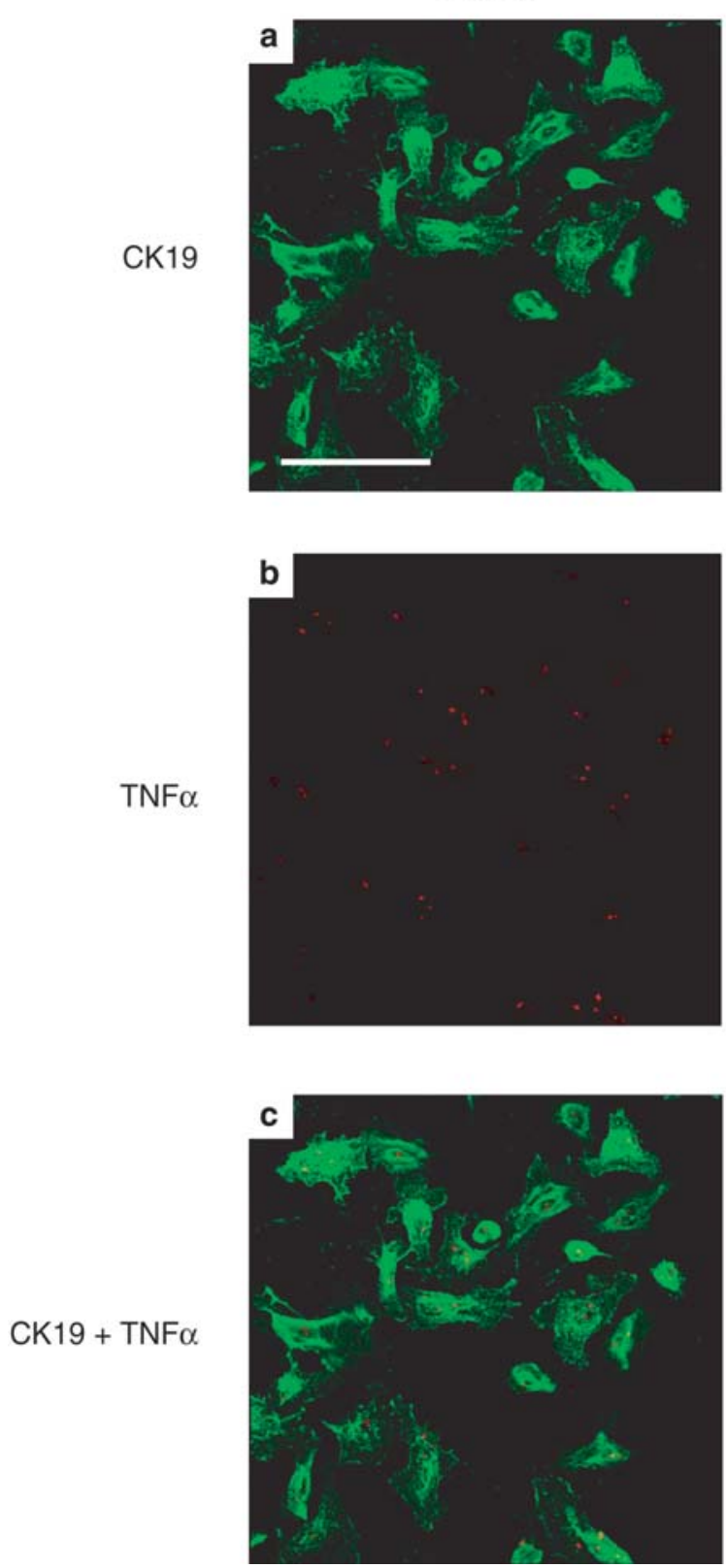

IL-1 1 + Brefeldin A
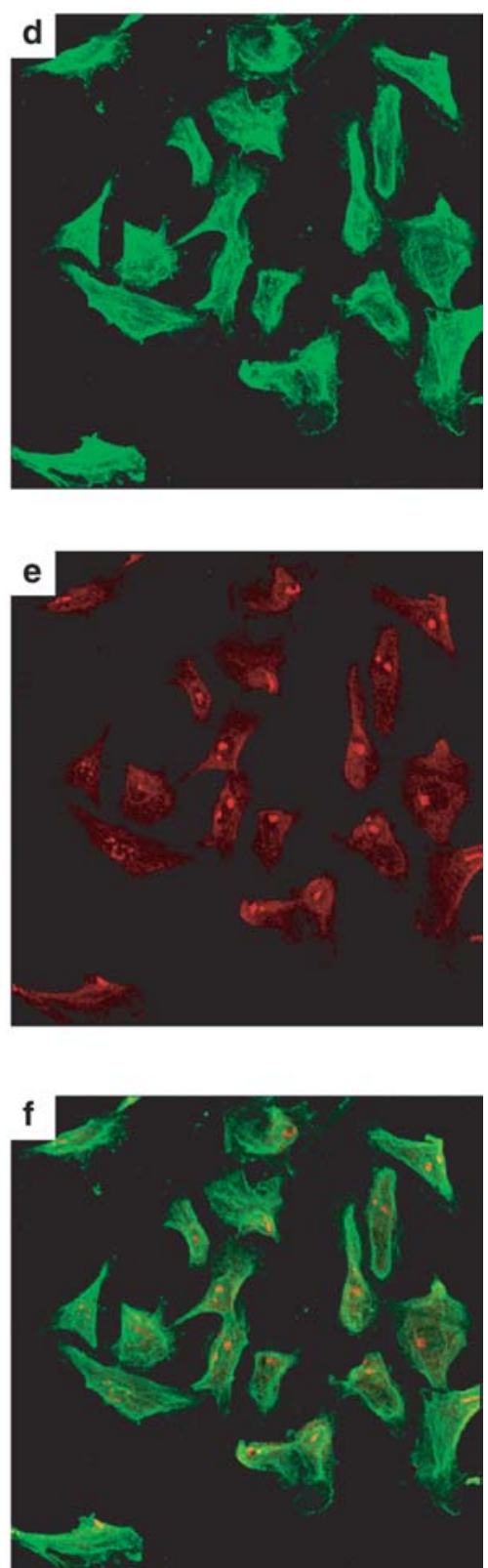

Fig. 4. Immunolocalisation of cellular Cytokeratin 19 (CK19) and TNF $\alpha$ by confocal laser scanning microscopy. Maximal projection images of human pancreatic duct cell monolayers incubated during $4 \mathrm{~h}$ with IL-1 $\beta(30 \mathrm{U} / \mathrm{ml})$ plus Brefeldin A $(5 \mu \mathrm{g} / \mathrm{ml})(\mathbf{d}-\mathbf{f})$ or medium alone (Control) $(\mathbf{a}-\mathbf{c})$. Cells were stained for TNF $\alpha$ (Texas Red) (b, c, e, f) and CK19 (CY2: green) (a, c, d, f). Scale bar: $50 \mu \mathrm{m}$

antibody (Fig. 7). None of the conditions increased the percentage of necrotic cells (Fig. 7).

Dendritic cell activation by duct-cell-released TNF. We examined whether duct cell medium was able to induce dendritic cell activation, which is known to be TNF $\alpha$-dependent. Immature dendritic cells were cultured for $24 \mathrm{~h}$ in DuC-IL-1 or DuC-Co and then evalu- ated for their expression of the activation markers CD25 (IL-2 receptor), CD80 (co-stimulatory molecule B7.1) and CD83 (maturation marker). Each experiment contained a positive control consisting of immature dendritic cells that were cultured with a mixture of cytokines (IL-1 $\beta$, IL-6, TNF $\alpha$ and PGE2); this condition induced at least $30 \%$ positive cells above control for these three markers (data not shown). In medium without cytokines, less than $6 \%$ positive cells were detected. Culture of immature dendritic cells in DuC-Co did not result in their activation as judged from the percentage of CD25, CD80 and CD83 cells ( $<6 \%$, NS vs negative control). On the other hand, DuC-IL-1 medium induced a significant increase in CD25, CD80 and CD83 expressing cells (Fig. 8). This effect was significantly suppressed by the anti-TNF $\alpha$ antibody (Fig. 8). 


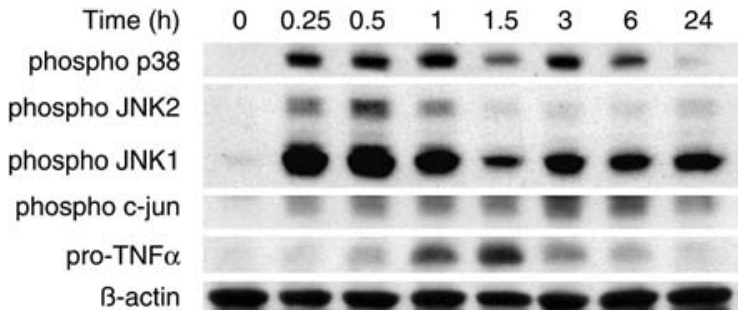

Fig. 5. Effect of IL-1 $\beta$ on MAP kinase phosphorylation. Monolayers of human pancreatic duct cells were incubated with IL-1 $\beta$ (30 U/ml) for the indicated times. Whole cell lysates were separated by SDS-PAGE and immunoblotted by the indicated antibodies. The figure represents three independent experiments

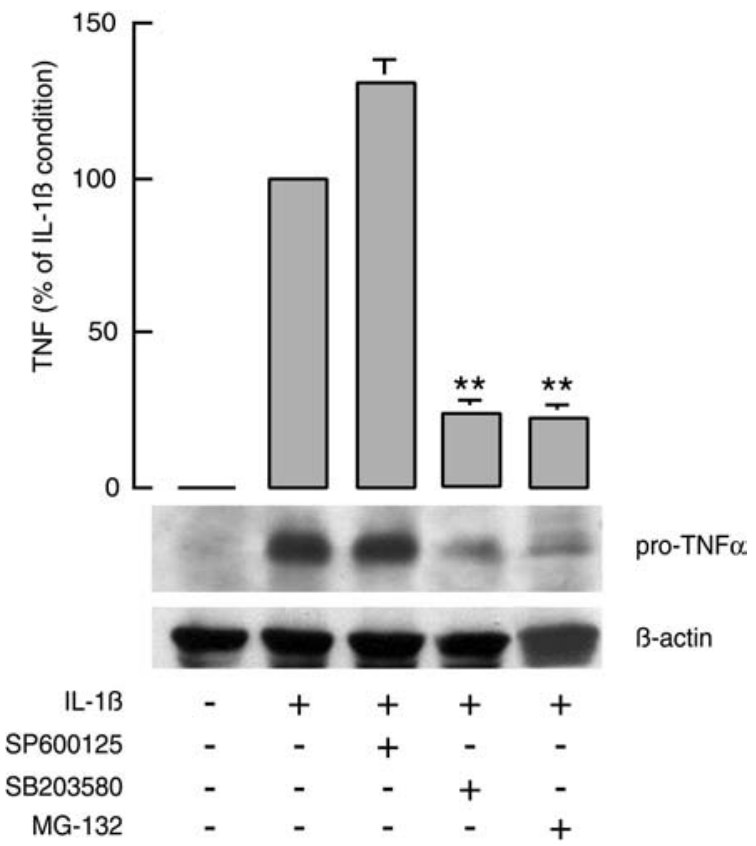

Fig. 6. Effects of SP600125, SB203580, and MG-132 on $\mathrm{TNF} \alpha$ production and secretion. Monolayers of human pancreatic duct cells were pre-treated for $1 \mathrm{~h}$ with SP600125 $(10 \mu \mathrm{mol} / \mathrm{l})$ or $\mathrm{SB} 203580(5 \mu \mathrm{mol} / \mathrm{l})$ or for $30 \mathrm{~min}$ with MG-132 $(50 \mu \mathrm{mol} / \mathrm{l})$ before exposure to IL-1 $\beta(30 \mathrm{U} / \mathrm{ml})$ for $6 \mathrm{~h}$. Whole cell lysates were separated by SDS-PAGE and immunoblotted by the indicated antibodies. Supernatants were harvested and assayed for TNF $\alpha$. Data are expressed as percent of IL- $1 \beta$ condition and represent means \pm SEM of three to six independent experiments. $* * p<0.01$ vs IL- $1 \beta$ alone

\section{Discussion}

In the developing pancreas, the juxtaposition of beta cells and duct cells is often noticed, and considered as indirect evidence for a ductal origin of beta cells. A similar topographic relationship exists in the adult human pancreas where $15 \%$ of insulin-producing cells occur as single units along ductules, and where beta cell aggregates are often directly juxtaposed to duct cells [20]. This anatomic characteristic explains why high numbers of duct cells co-migrate with endocrine
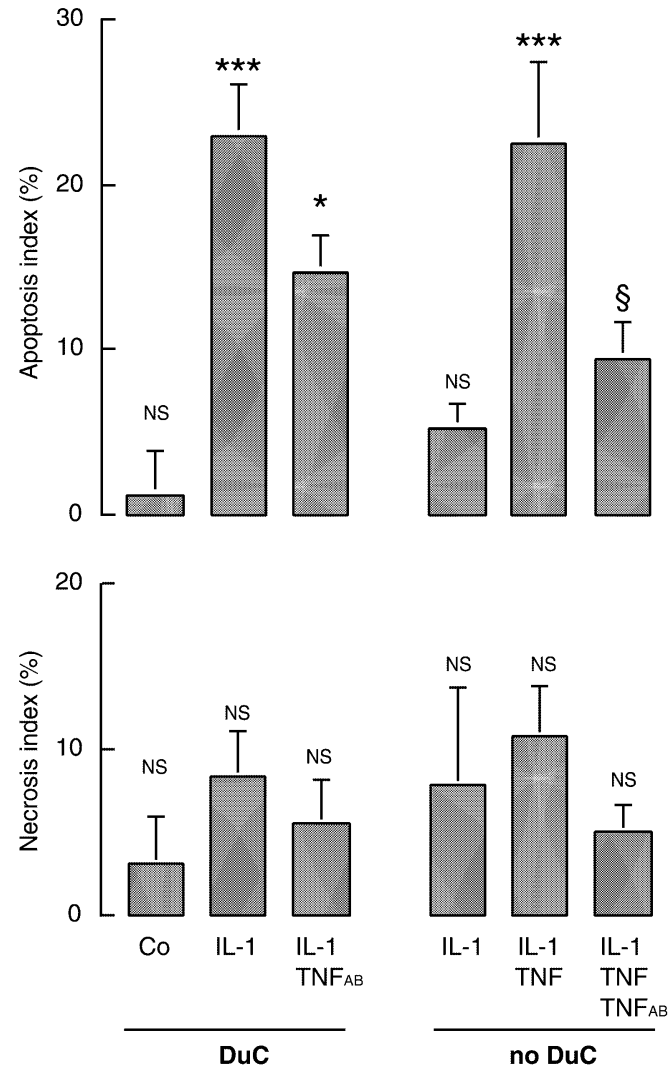

Fig. 7. Effect of duct cell medium on viability of cultured human pancreatic beta cells. FACS purified human pancreatic beta cells were cultured with medium (DuC) that was collected from human duct cell monolayers, which had been incubated for $24 \mathrm{~h}$ in the absence $(\mathrm{Co})$ or presence of IL-1 $\beta$ at $30 \mathrm{U} / \mathrm{ml}$ (IL-1). After 10 days of culture the number of apoptotic and necrotic cells were counted and expressed relative to the numbers in control preparations cultured in unconditioned medium. For each condition an apoptosis and necrosis index was calculated as defined in reference [27]. The right panel shows data for cells cultured in unconditioned medium (no DuC) in the presence of IL-1 $\beta$ (30 U/ml) with or without TNF $\alpha$ $(400 \mathrm{pg} / \mathrm{ml})$. The role of $\mathrm{TNF} \alpha$ was assessed by adding a $\mathrm{TNF} \alpha$ neutralising antibody $\left(\mathrm{TNF}_{\mathrm{AB}}\right)$ to the conditions DuCIL-1 and IL-1 $\beta+$ TNF $\alpha$. Data represent means \pm SEM of three independent experiments. $* * * p<0.001$ vs control, $* p<0.05$ vs DuC IL- $1 \beta, \S p<0.05$ vs IL- $1 \beta+$ TNF $\alpha$

cells during human islet isolation $[21,22]$. The presence of 20 to $60 \%$ duct cells in human beta cell grafts led us to examine whether they might be involved in inflammatory and immune reactions around islet cell implants. We previously reported that human duct cells can respond to cytokines by expressing MHCclass II and iNOS with subsequent NO production $[17,18]$. Our data show that these cells can also release TNF $\alpha$ at levels that affect survival of neighbouring beta cells and activate dendritic cells.

Duct cell release of TNF $\alpha$ was induced by interleukin-1ß. While this in vitro condition only serves as a model to demonstrate the existence and the mechanism of this duct cell property, it may occur in vivo 

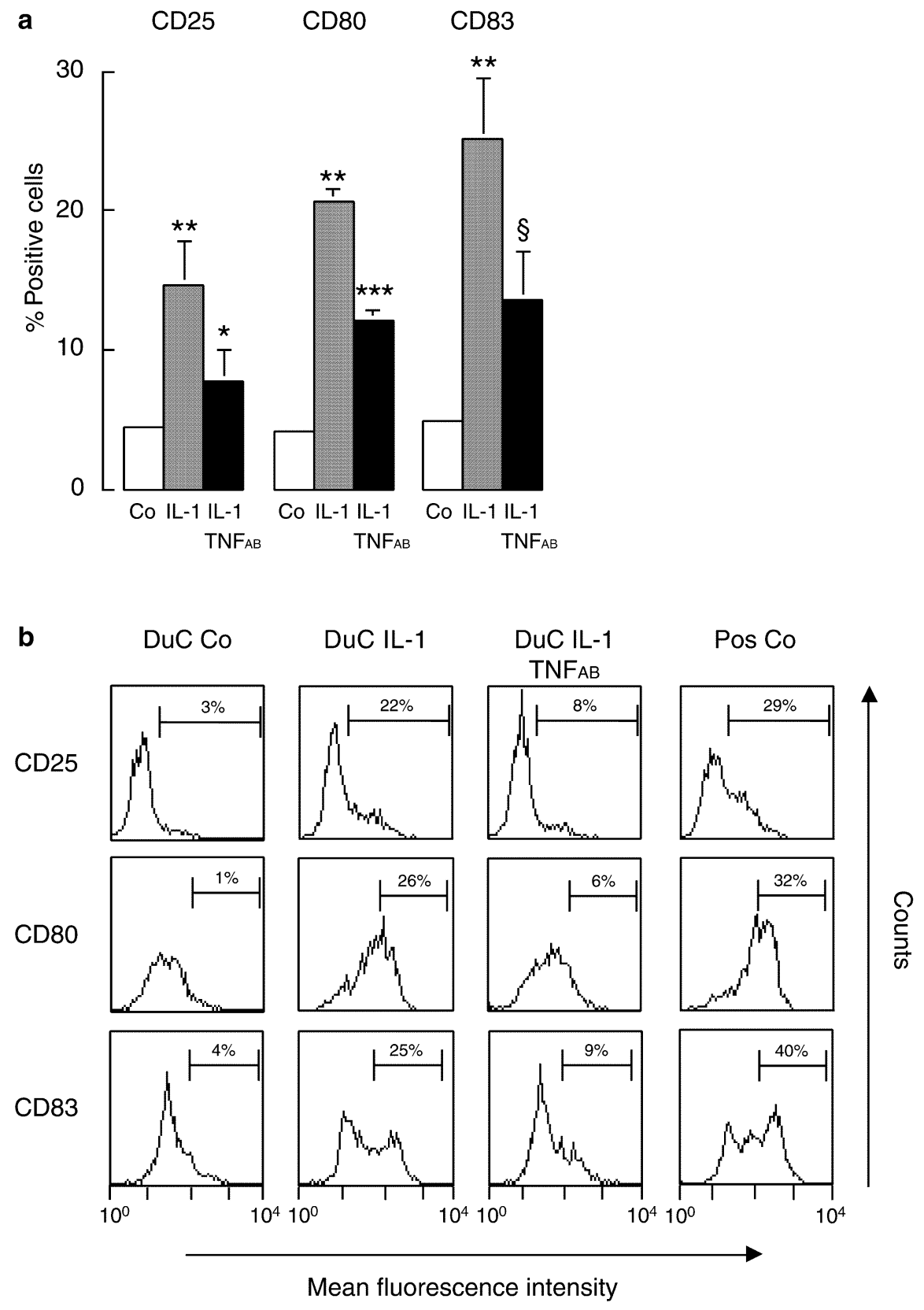

Fig. 8. Effect of duct cell medium on the activation of dendritic cells. Immature human dendritic cells were incubated for $24 \mathrm{~h}$ with medium that was collected from human duct cell monolayers, which had been incubated for $24 \mathrm{~h}$ in the absence (DuC-Co) or presence of IL-1 $\beta$ at $30 \mathrm{U} / \mathrm{ml}$ (DuC-IL-1). Their degree of activation was measured by FACS analysis of the percentage of CD25, CD80 and CD83 positive cells relative to the percentages in the negative control condition (a). Data represent means \pm SEM for three to five independent experiments. $* * p<0.01$ compared to control; * $p<0.05$; *** $p<0.001$; $\S p<0.05$ compared to DuC-IL-1. b. A representative flow diagram which also shows the degree of activation in the positive control condition (stimulation by IL-1 $\beta$, IL-6, TNF $\alpha$ and PGE2) when IL-1 $\beta$ is released by islet cells or by islet infiltrating cells [37]. TNF $\alpha$ release was dependent on the induction of TNF $\alpha$ precursor synthesis and conversion, rather than on discharge from a cellular pool of the converted mature form. The mechanism through which IL-1 $\beta$ induces TNF $\alpha$-expression in human pancreatic duct cells is not fully understood. As in other cell types [38], this IL-1 $\beta$ effect depends on activation of MAP kinase p38 and seems mediated, at least in part, by NF- $\mathrm{B}$, which is known to bind to the promoter region of TNF $\alpha$. On the other hand, it proceeds irrespective of iNOS induction or NO-production, and seems independent of JNK-activation, which contrasts with the mechanism in human CD4+ cells [36].

TNF $\alpha$ produced by human duct cells was shown to exert effects on neighbouring endocrine and immune 
cells. The cytokine is released in a biologically active form and rapidly reaches in vitro concentrations in the range used in numerous in vitro studies $[10,39,40]$. Among the functions known to be TNF $\alpha$ sensitive, survival of beta cells [41, 42] and activation of dendritic cells [43, 44, 45] seem particularly relevant in the context of the pathogenesis of Type 1 diabetes and strategies to prevent or cure the disease. Medium containing duct-cell-released TNF $\alpha$ induced apoptosis in human beta cell preparations, probably in synergy with IL- $1 \beta$ that was added to stimulate TNF $\alpha$ production. Studies on rodent and human beta cells have indeed indicated that IL-1 $\beta$ alone does not cause apoptosis unless it is combined with IFN- $\gamma$ and/or TNF $\alpha$ $[42,46]$. A neutralising anti-TNF $\alpha$ antibody partially suppressed the apoptotic effect of the duct cell medium; the lack of complete suppression may result from insufficient neutralisation by the antibody or by another factor that is induced by IL-1 $\beta$.

Pro-inflammatory cytokines such as IL-1 $\beta$ and TNF $\alpha$ are also known to stimulate migration and maturation of dendritic cells [43, 44, 45]. Our study shows that duct-cell-released TNF $\alpha$ can activate human dendritic cells, suggesting that these cells may play a role in the development of (auto)immune processes. Our data are compatible with earlier work showing TNF $\alpha$ involvement in the in vivo process of immune beta cell destruction. Neutralising TNF $\alpha$ antibodies were shown to protect NOD mice against diabetes, whereas treatment with recombinant TNF $\alpha$ accelerated the disease [11]. TNF $\alpha$ receptor 1 -deficient NOD mice did not develop diabetes although insulitis was present [12], whereas induction of TNF $\alpha$ expression in islets accelerated progression to diabetes [13]. The latter effect was attributed to an immune modulation at an earlier age, following apoptosis of a few beta cells and subsequent activation of islet dendritic cells [14]. When islet TNF expression was regulated by a tetracycline-driven on-off switch, progression to diabetes depended on the duration of exposure to TNF $\alpha$ [15]. Another study showed the importance of timing islet-specific TNF $\alpha$ expression with respect to the autoimmune process [16]. These studies explain why the diabetogenic effects of TNF $\alpha$ were not observed when islet-specific TNF $\alpha$ expression was restricted to later stages [47]. It is also conceivable that local release of this cytokine alters the phenotype of neighbouring beta cells and thus varies their susceptibility to cytotoxic conditions as previously observed with interleukin-1 [48]. In the presence of other cytokines, TNF $\alpha$ may itself contribute to the death of beta cells [42]; in this respect, production of interleukin- 1 by beta cells could be considered as a potential local trigger [37].

In conclusion, human pancreatic duct cells should be considered as potential participants in (auto)immune processes that occur during development of Type 1 diabetes or after islet transplantation. Their exposure to cytokines can induce expression of MHCclass II [17], iNOS [18] and/or TNF $\alpha$ precursor. It is still unknown whether these diverse responses can be generated by all duct cells or whether they characterise a particular subpopulation. Our in vitro observation that duct-cell-released TNF $\alpha$ can affect survival of human beta cells and activate human dendritic cells might bear clinical relevance, in particular since these different cell types are closely associated during development of Type 1 diabetes $[1,2]$ as well as during islet allograft reactivity.

Acknowledgements. This work was supported by grants from the Belgian Fund for Scientific Research, Flanders (G.0375.00), the Belgian Interuniversity Attraction Poles (IUAP P5/17), European Foundation for the Study of Diabetes and The Juvenile Diabetes Research Foundation (4-2001-434). B. Movahedi is a research fellow (aspirant) of the Belgian Fund for Scientific Research, Flanders. The authors thank the staff of the Beta Cell Bank for providing the (non-)endocrine tissue fractions, Nicole Buelens and Maarten Timmers for their expert contribution to the immunocytochemical studies, Lut Overbergh and Dirk Valckx for providing primers and probes for real time PCR, and Johan Guns for excellent technical assistance.

\section{References}

1. Gepts W (1965) Pathologic anatomy of the pancreas in juvenile diabetes mellitus. Diabetes 14:619-633

2. Pipeleers D, Ling Z (1992) Pancreatic beta cells in insulindependent diabetes. Diabetes Metab Rev 8:209-227

3. Bottazzo GF, Dean BM, McNally JM, MacKay EH, Swift PG, Gamble DR (1985) In situ characterization of autoimmune phenomena and expression of HLA molecules in the pancreas in diabetic insulitis. $\mathrm{N}$ Engl $\mathrm{J}$ Med 313:353-360

4. Mori Y, Suko M, Okudaira H et al. (1986) Preventive effects of cyclosporine on diabetes in NOD mice. Diabetologia 29:244-247

5. Held W, MacDonald HR, Weissman IL, Hess MW, Mueller C (1990) Genes encoding tumor necrosis factor alpha and granzyme A are expressed during development of autoimmune diabetes. Proc Natl Acad Sci USA 87:22392243

6. Rabinovitch A (1994) Immunoregulatory and cytokine imbalances in the pathogenesis of IDDM. Therapeutic intervention by immunostimulation? Diabetes 43:613621

7. Welsh M, Welsh N, Bendtzen K et al. (1995) Comparison of mRNA contents of interleukin-1 beta and nitric oxide synthase in pancreatic islets isolated from female and male nonobese diabetic mice. Diabetologia 38:153-160

8. Pilstrom B, Bjork L, Bohme J (1997) Monokine-producing cells predominate in the recruitment phase of NOD insulitis while cells producing Th1-type cytokines characterize the effector phase. J Autoimmun 10:147-155

9. Mandrup-Poulsen T (1996) The role of interleukin-1 in the pathogenesis of IDDM. Diabetologia 39:1005-1029

10. McDaniel ML, Kwon G, Hill JR, Marshall CA, Corbett JA (1996) Cytokines and nitric oxide in islet inflammation and diabetes. Proc Soc Exp Biol Med 211:24-32 
11. Yang XD, Tisch R, Singer SM et al. (1994) Effect of tumor necrosis factor alpha on insulin-dependent diabetes mellitus in NOD mice. I. The early development of autoimmunity and the diabetogenic process. J Exp Med 180:995-1004

12. Kagi D, Ho A, Odermatt B, Zakarian A, Ohashi PS, Mak TW (1999) TNF receptor 1-dependent beta cell toxicity as an effector pathway in autoimmune diabetes. J Immunol 162:4598-4605

13. Green EA, Eynon EE, Flavell RA (1998) Local expression of TNFalpha in neonatal NOD mice promotes diabetes by enhancing presentation of islet antigens. Immunity 9:733743

14. Green EA, Flavell RA (1999) Tumor necrosis factor-alpha and the progression of diabetes in non- obese diabetic mice. Immunol Rev 169:11-22

15. Green EA, Flavell RA (2000) The temporal importance of TNFalpha expression in the development of diabetes. Immunity 12:459-469

16. Christen U, Wolfe T, Mohrle U et al. (2001) A dual role for TNF-alpha in type 1 diabetes: islet-specific expression abrogates the ongoing autoimmune process when induced late but not early during pathogenesis. J Immunol 166:70237032

17. Pavlovic D, Winkel M van de, Auwera B van der et al. (1997) Effect of interferon-gamma and glucose on major histocompatibility complex class I and class II expression by pancreatic beta- and non-beta-cells. J Clin Endocrinol Metab 82:2329-2336

18. Pavlovic D, Chen MC, Bouwens L, Eizirik DL, Pipeleers D (1999) Contribution of ductal cells to cytokine responses by human pancreatic islets. Diabetes 48:29-33

19. Pipeleers D, Hoorens A, Marichal-Pipeleers M, Van de Casteele M, Bouwens L, Ling Z (2001) Role of pancreatic beta-cells in the process of beta-cell death. Diabetes 50 [Suppl 1]:S52-S57

20. Bouwens L, Pipeleers DG (1998) Extra-insular beta cells associated with ductules are frequent in adult human pancreas. Diabetologia 41:629-633

21. Ling Z, Pipeleers DG (1996) Prolonged exposure of human beta cells to elevated glucose levels results in sustained cellular activation leading to a loss of glucose regulation. J Clin Invest 98:2805-2812

22. Keymeulen B, Ling Z, Gorus FK et al. (1998) Implantation of standardized beta-cell grafts in a liver segment of IDDM patients: graft and recipients characteristics in two cases of insulin-independence under maintenance immunosuppression for prior kidney graft. Diabetologia 41:452-459

23. Green LC, Wagner DA, Glogowski J, Skipper PL, Wishnok JS, Tannenbaum SR (1982) Analysis of nitrate, nitrite, and $[15 N]$ nitrate in biological fluids. Anal Biochem 126:131138

24. Overbergh L, Giulietti A, Valckx D, Decallonne R, Bouillon R, Mathieu C (2003) The use of real-time reverse transcriptase PCR for the quantification of cytokine gene expression. J Biomol Tech 14:33-43

25. Pipeleers DG, in't Veld PA, Van de Winkel M, Maes E, Schuit FC, Gepts W (1985) A new in vitro model for the study of pancreatic A and B cells. Endocrinology 117:806816

26. Hoorens A, Van de Casteele M, Kloppel G, Pipeleers D (1996) Glucose promotes survival of rat pancreatic beta cells by activating synthesis of proteins which suppress a constitutive apoptotic program. J Clin Invest 98:15681574

27. Pipeleers D, Van de Winkel M (1986) Pancreatic B cells possess defense mechanisms against cell-specific toxicity. Proc Natl Acad Sci USA 83:5267-5271
28. Romani N, Reider D, Heuer M et al. (1996) Generation of mature dendritic cells from human blood. An improved method with special regard to clinical applicability. J Immunol Methods 196:137-151

29. Tuyaerts S, Noppe SM, Corthals J et al. (2002) Generation of large numbers of dendritic cells in a closed system using Cell Factories. J Immunol Methods 264:135-151

30. Jonuleit H, Kuhn U, Muller G et al. (1997) Pro-inflammatory cytokines and prostaglandins induce maturation of potent immunostimulatory dendritic cells under fetal calf serum-free conditions. Eur J Immunol 27:31353142

31. Breckpot K, Dullaers M, Bonehill A et al. (2003) Lentivirally transduced dendritic cells as a tool for cancer immunotherapy. J Gene Med 5:654-667

32. Dinter A, Berger EG (1998) Golgi-disturbing agents. Histochem Cell Biol 109:571-590

33. Shurety W, Merino-Trigo A, Brown D, Hume DA, Stow JL (2000) Localization and post-Golgi trafficking of tumor necrosis factor-alpha in macrophages. J Interferon Cytokine Res 20:427-438

34. Cuenda A, Rouse J, Doza YN et al. (1995) SB 203580 is a specific inhibitor of a MAP kinase homologue which is stimulated by cellular stresses and interleukin-1. FEBS Lett 364:229-233

35. Kwon G, Corbett JA, Hauser S, Hill JR, Turk J, McDaniel ML (1998) Evidence for involvement of the proteasome complex (26S) and NfkappaB in IL-1beta-induced nitric oxide and prostaglandin production by rat islets and RINm5F cells. Diabetes 47:583-591

36. Bennett BL, Sasaki DT, Murray BW et al. (2001) SP600125, an anthrapyrazolone inhibitor of Jun N-terminal kinase. Proc Natl Acad Sci USA 98:13681-13686

37. Heitmeier MR, Arnush M, Scarim AL, Corbett JA (2001) Pancreatic beta-cell damage mediated by beta-cell production of interleukin-1. A novel mechanism for virus-induced diabetes. J Biol Chem 276:11151-11158

38. Raingeaud J, Gupta S, Rogers JS et al. (1995) Pro-inflammatory cytokines and environmental stress cause p38 mitogen- activated protein kinase activation by dual phosphorylation on tyrosine and threonine. J Biol Chem 270:74207426

39. Hoorens A, Pipeleers D (1999) Nicotinamide protects human beta cells against chemically-induced necrosis, but not against cytokine-induced apoptosis. Diabetologia 42:5559

40. Mandrup-Poulsen T, Helqvist S, Wogensen LD et al. (1990) Cytokine and free radicals as effector molecules in the destruction of pancreatic beta cells. Curr Top Microbiol Immunol 164:169-193

41. Delaney CA, Pavlovic D, Hoorens A, Pipeleers DG, Eizirik DL (1997) Cytokines induce deoxyribonucleic acid strand breaks and apoptosis in human pancreatic islet cells. Endocrinology 138:2610-2614

42. Mandrup-Poulsen T, Bendtzen K, Dinarello CA, Nerup J (1987) Human tumor necrosis factor potentiates human interleukin 1-mediated rat pancreatic beta-cell cytotoxicity. J Immunol 139:4077-4082

43. Yamaguchi Y, Tsumura H, Miwa M, Inaba K (1997) Contrasting effects of TGF-beta 1 and TNF-alpha on the development of dendritic cells from progenitors in mouse bone marrow. Stem Cells 15:144-153

44. Rieser C, Bock G, Klocker H, Bartsch G, Thurnher M (1997) Prostaglandin E2 and tumor necrosis factor alpha cooperate to activate human dendritic cells: synergistic activation of interleukin 12 production. J Exp Med 186:1603-1608 
45. Zhou LJ, Tedder TF (1996) CD14+ blood monocytes can differentiate into functionally mature CD83+ dendritic cells. Proc Natl Acad Sci USA 93:2588-2592

46. Pukel C, Baquerizo H, Rabinovitch A (1988) Destruction of rat islet cell monolayers by cytokines. Synergistic interactions of interferon-gamma, tumor necrosis factor, lymphotoxin, and interleukin 1. Diabetes 37:133-136

47. Grewal IS, Grewal KD, Wong FS, Picarella DE, Janeway CA Jr, Flavell RA (1996) Local expression of transgene encoded TNF alpha in islets prevents autoimmune diabetes in nonobese diabetic (NOD) mice by preventing the development of auto-reactive islet-specific T cells. J Exp Med 184:1963-1974

48. Ling Z, Van de Casteele M, Eizirik DL, Pipeleers DG (2000) Interleukin-1beta-induced alteration in a beta-cell phenotype can reduce cellular sensitivity to conditions that cause necrosis but not to cytokine-induced apoptosis. Diabetes 49:340-345 